Journal of Engineering and Applied Sciences 14 (Special Issue 2): 5514-5521, 2019

ISSN: 1816-949X

(C) Medwell Journals, 2019

\title{
Comparison Between the Energy Utilization Efficiency and the Specific Resistance of Single Tine, Double Tines Parallel and Partially Swerved Double Tines Subsoilers
}

\author{
S.H. Aday and M. Ramdhan \\ Department of Agricultutre Machines and Equipment, College of Agricultutre, University of Basra, \\ Basra, Iraq, shaker.h.1953@gmail.com
}

\begin{abstract}
Three subsoiler combinations namely single tine (conventional Subsoiler) (S), double tines parallel arranged, the lateral distance between them is $70 \mathrm{~cm}$ (SSP) and partially swerved double tines, the lateral and longitudinal distances between the two tines are $70 \mathrm{~cm}$ (SSV). The three subsoiler combinations were examined with and without wings and four operating depths $(30-60 \mathrm{~cm})$ The soil texture was of silty clay. The moisture content level of the soil (average) is $13.54 \%$. The field performance of the three subsoiler combinations depends on the tines arrangement. The lateral interference between the two tines for high performance should be not $<25 \%$ otherwise, the two tines operate separately or leave high tappet of undisturbed soil between them. SSV surpassed S and SSP while S surpassed SSP in reducing SR with operating depths and with and without wings in both sites. SR for SSV, S and SSP decreased from 113.74-58.78 $\mathrm{kNm}^{-2}, 149.45-71.78 \mathrm{kNm}^{-2}$ and $167.03-72.04 \mathrm{kNm}^{-2}$ when they were provided with wings and their operating depth increased from $30-60 \mathrm{~cm}$, respectively. SSV supervised S and SSP in giving higher EUE whereas S supervised SSP with and without wings for all operating depths in both sites. EUE for SSV, S and SSP increased from 8.84-17.15 $\mathrm{m}^{3} \mathrm{MJ}^{-1}(107 \%)$, $6.73-13.93 \mathrm{~m}^{3} \mathrm{MJ}^{-1}(94 \%)$ and $5.99-13.88 \mathrm{~m}^{3} \mathrm{MJ}^{-1}(131 \%)$ when they were provided with wing and their operating depths increased from $30-60 \mathrm{~cm}$, respectively. The field observations showed that SSP suffered from soil blockade, low soil flow between its two tines. Increasing the lateral distance between its two tines to reduce the soil blockade resulted in that each tine operates separately and the helpmate between them ether diminished completely or at low scale which lead to low volume of soil disturbance and that would end the aim of using double tines.
\end{abstract}

Key words: SSV, SR, SSP, EUE, DA, soil

\section{INTRODUCTION}

The aims of using the subsoiler are to disturb the soil to a certain depth to improve its ability to infiltrate the excess water washing the soil salinity down, encouraging the microorganism activity to improve the soil fertility and to prevent plant roots impeding (Godwin et al., 1984). These aims can be achieved by a subsoiler provided a suitable soil conditions present at the time of the operation as well as some essential modification should be carried out on the subsoiler to improve its performance. The suitable soil conditions and the subsoiler modification can produce greater volume of disturbed soil to improve soil physical properties. The modifications to be carried out on the conventional subsoiler include the following: providing the subsoiler with two shallow tines working ahead of it and attached wings to its foot. However, using two shallow tines sometimes when the soil conditions are not suitable do not produce the required field performance thus replacing them by a tine similar to the conventional one, i.e., changing the single conventional subsoiler to double tines subsoiler (McKyes and Ali, 1977; McKeys and Maswaure, 1997; O'callaghan and McCullen, 1965; Owen, 1988).

The performance of the double tines subsoiler actually depend on the arrangement of the two tines as well as the soil condition (Aday et al., 2004; McKyes and Desir, 1984; Ramadan, 2011). The arrangement of the double tines of the subsoiler determine the flow of the disturbed soil between them which determines the draft force requirement of the subsoiler. The two tines can be arranged in two ways either parallel, the two tines laterally on the same line or partially swerved, one tine ahead of the other but swerved sideways to make a lateral distance between them.

The specific resistance of the conventional subsoiler and the modified one which was provided with two shallow decreased with increasing the operating depth

Corresponding Author: S.H. Aday, Department of Agricultutre Machines and Equipment, College of Agricultutre, University of Basra, Basra, Iraq, shaker.h.1953@gmail.com 
in uncultivated and cultivated soils (Aday, 2012; Aday et al., 2004; Godwin and Spoor, 1977). The modified subsoiler surpassed the conventional subsoiler in giving lower specific resistance and that regarded as improvement in the field performance of the modified subsoiler. The specific resistance of a manure laying machine provided with subsoiler decreased from $116.67-64.92 \mathrm{kNm}^{-2}$ (44.35\%) when the operating depth increased from $20-60 \mathrm{~cm}$ (Godwin et al., 1984). The specific resistance of the subsoiler decreased from $126-104 \mathrm{kNm}^{-2}$ when the subsoiler was provided with wings of $30 \mathrm{~cm}$ wide at operating depth of $36 \mathrm{~cm}$ (Godwin and Spoor, 1977).

EUE for single tines subsoiler increased from 7.28-12.08 $\mathrm{m}^{3} \mathrm{MJ}^{-1}$ when the operating depth increased from $30-50 \mathrm{~cm}$ in silty clay soil (Aday et al., 2001; Aday, 2005). In another studied EUE of the single tine subsoiler in silty clay soil of MC of $23.26 \%$, EUE increased from 5.71-6.96 $\mathrm{m}^{3} \mathrm{MJ}^{-1}$ when the subsoiler foot was provided with wings of $27 \mathrm{~cm}$ wide at operation depth of $50 \mathrm{~cm}$ (Aday, 2012; Aday et al., 2001). The operating depth appreciably affected EUE, it increased from 12.08-14.19 $\mathrm{m}^{3} \mathrm{MJ}^{-1}$ when the operating depth increased from $30-50 \mathrm{~cm}$ (Aday et al., 2004). The specific resistance of the subsoiler decreased from $126-104 \mathrm{kNm}^{-2}$ when the subsoiler was provided with wings of $30 \mathrm{~cm}$ wide at operating depth of $36 \mathrm{~cm}$ (Aday et al., 2004).

In this research the field performance of the two tines arrangements will be examined and compared with single tine subsoiler (conventional subsoiler) To determine the best tines arrangement giving lower specific resistance and higher energy utilization efficiency.

\section{MATERIALS AND METHODS}

The experiments were conducted using three subsoiler combinations namely, single tine Subsoiler (S), parallel double tines subsoiler (SSP) and partially swerved double tines subsoiler (SSV).

The three subsoilers descriptions are: the leg (shank) forward inclination angle (rake angle) is $66^{\circ}$, the foot inclination angle relative to the front of the leg is $117^{\circ}$ (Fig. 1). The foot attack angle is $35^{\circ}$. The lateral distance between the parallel tines is $70 \mathrm{~cm}$. The forward and lateral distances between the partially swerved double tines subsoiler are equals $(70 \mathrm{~cm}$ ) (Fig. 2). The feet of the two tines were provided with wings at some stages of the experiments. The effective width of the winds was $28 \mathrm{~cm}$ (Fig. 3).

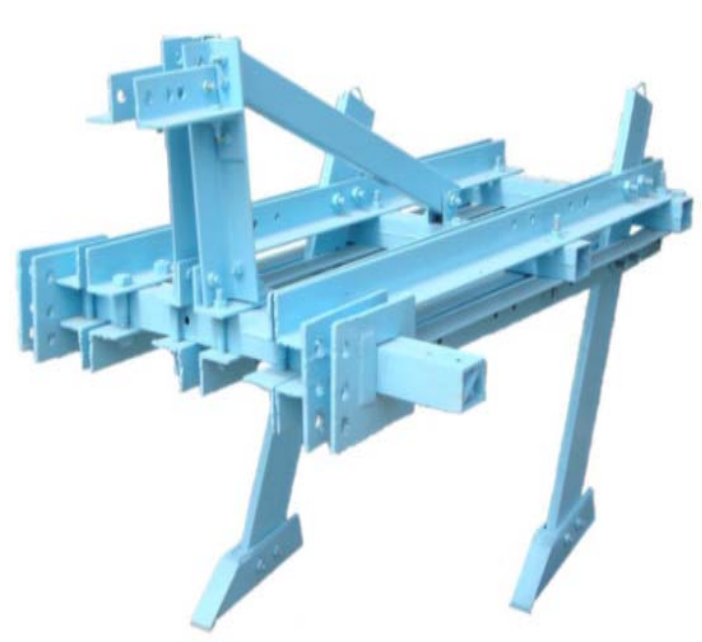

Fig. 1: The partially swerved double tine subsoiler

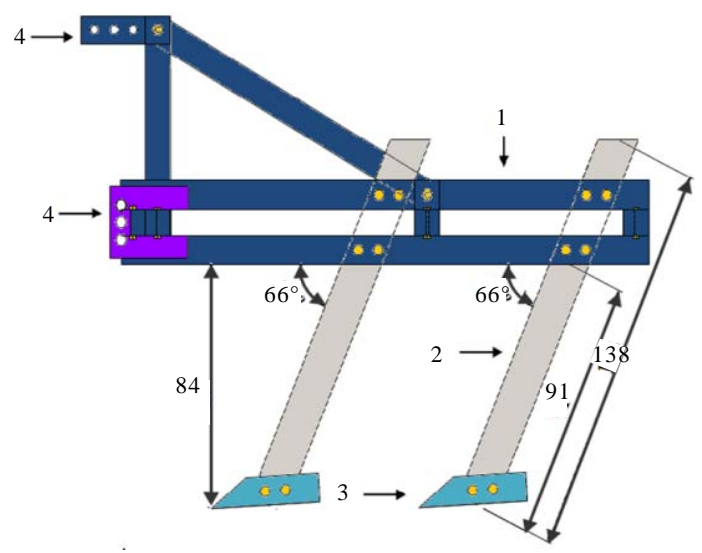

Fig. 2: Side view of the partially swerved double tines subsoiler

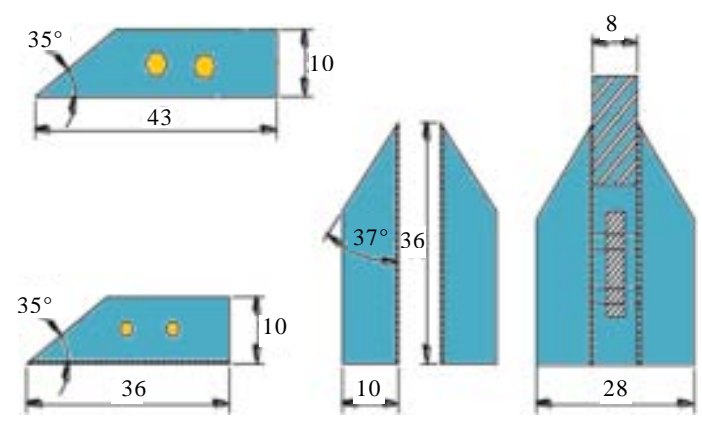

Fig. 3: The dimensions of the foot and the wings

The experiments were carried out in silty clay loam soil. The soils physical and mechanical properties are shown in Table 1 and 2 . The experiments parameters are three subsoiler combinations namely single tine Subsoiler (S), parallel double tines subsoiler (SSP) and partially 


\begin{tabular}{|c|c|c|c|c|c|c|c|}
\hline Depth $(\mathrm{cm})$ & $\begin{array}{l}\text { Moisture content } \\
(\%)\end{array}$ & $\begin{array}{c}\text { Soil bulk density } \\
\left({\left.\mathrm{Mg} \cdot \mathrm{m}^{-3}\right)}\right.\end{array}$ & $\begin{array}{l}\text { Soil cone index } \\
\left(\mathrm{kN} \cdot \mathrm{m}^{-2}\right)\end{array}$ & Sand (g. $\left.\mathrm{kg}^{-1}\right)$ & Silt $\left(\mathrm{g} \cdot \mathrm{kg}^{-1}\right)$ & $\begin{array}{l}\text { Clay } \\
(\text { g.kg-1) }\end{array}$ & Soil texture \\
\hline $0-10$ & 7.690 & 1.37 & 1794.72 & 19.80 & 782.95 & 197.25 & Silt loam \\
\hline $10-20$ & 9.870 & 1.41 & 3948.38 & 19.85 & 706.43 & 273.72 & Silty clay loam \\
\hline $20-30$ & 11.25 & 1.46 & 5743.11 & 18.07 & 640.20 & 341.73 & Silty clay loam \\
\hline $30-40$ & 16.04 & 1.52 & 6640.47 & 17.43 & 582.85 & 399.71 & Silty clay loam \\
\hline $40-50$ & 16.77 & 1.60 & 6999.41 & 11.10 & 584.30 & 404.58 & Silty clay \\
\hline $50-60$ & 19.63 & 1.58 & 5743.11 & 11.99 & 573.90 & 414.11 & Silty clay \\
\hline Average of depths & 13.54 & 1.49 & 5144.86 & & & & \\
\hline
\end{tabular}

Table 2: The mechanical properties of the soil

\begin{tabular}{|c|c|c|c|c|}
\hline Depth (cm) & Soil cohesion $\left(\mathrm{kN} \cdot \mathrm{m}^{-2}\right)$ & Angle of internal friction $\left(^{\circ}\right)$ & Soil adhesion $\left(\mathrm{kN} \cdot \mathrm{m}^{-2}\right)$ & Friction between the metal and the soil $\left(^{\circ}\right)$ \\
\hline $0-10$ & 6.69 & 19 & 0.158 & 33.70 \\
\hline $10-20$ & 8.27 & 17 & & \\
\hline $20-30$ & 10.11 & 20 & & \\
\hline $30-40$ & 11.26 & 23 & & \\
\hline $40-50$ & 13.27 & 26 & & \\
\hline $50-60$ & 12.38 & 25 & & \\
\hline $\begin{array}{l}\text { Average of } \\
\text { depths }\end{array}$ & 10.33 & 21.66 & & \\
\hline
\end{tabular}

swerved double tines subsoiler (SSV) and four operating depths of $20-60 \mathrm{~cm}$. S, SSV and SSP were used with wings and without wings.

The draft force measurement: The draft force requirement was measured by a load cell which was conducted to laptop computer mounted on the tractor. The experiments were carried out as follows: each subsoiler combination was mounted on a tractor. The tractor-subsoiler combination was towed by another tractor. The load cell was mounted between the two tractors. The operating depth was predetermined by lowering the subsoiler in the soil and then left to move distance of about 3-5 $\mathrm{m}$ to approach the right depth. The gear box of the towed tractor-subsoiler combination was put in natural. The engine speed of the towing tractor was approximately fixed at $1500 \mathrm{rpm}$ and then its gear box was put in gear. The draft force was measured as soon as the towed tractor approached the maximum forward speed. The measurements continued for distance of $15 \mathrm{~m}$. Each run was repeated three times. The actual time spent to move $15 \mathrm{~m}$ was also measured by timing watch. The rolling resistance of the towed tractor was measured in the experiment sites by pulling the towed tractor-subsoiler combination using the load cell. The subsoiler during the measurement was out of the soil but left parallel to the soil surface to reduce the transfer weight from the front wheels to the rear wheels. The draft force of the subsoilers was calculated by subtracting the total draft force from the rolling resistance of the towed tractor, Eq. 1:

$$
\mathrm{F}=\mathrm{Ft}-\mathrm{R}
$$

Disturbed area: The disturbed area by the subsoiler combinations (Fig. 4) was calculated using Eq. 2. The soil of each run was dogged out in three different positions which were selected randomly. The soil digging was carried out by hand to reduce the failure of soil of the channel's sides. The dimensions of the cross-section area of the disturbed soil (channel) were measured. The actual dimensions were represented by Fig. 4a single tine without wings, single tine with wings and double parallel and partially swerved subsoilers. The disturbed area by the single tine is calculated by Eq. 2 :

$$
A=d \times w+s . d c
$$

The disturbed area by the winged subsoiler is represented by (Fig. 4b). It is calculated by Eq. 3:

$$
\mathrm{A}=\frac{\mathrm{b}+\mathrm{W}_{\mathrm{i}}}{2} \mathrm{~d}
$$

The disturbed area by the parallel double tines and partially swerved double tines subsoilers is shown in Fig. 4c. It is calculated by Eq. 4 :

$$
\mathrm{A}=\frac{1}{2}\left(\mathrm{~b}_{1}+\mathrm{b}_{2}\right) \mathrm{d}_{1}-\mathrm{W}\left(\mathrm{d}_{1}-\mathrm{d}_{2}\right)
$$

The experiment design was completed randomize design factorial experiment of three factors $(4 \times 2 \times 3)$. The means of the treatments were compared using RLSD at probability of $5 \%$.

Specific resistance: The specific resistance of the three subsoiler combinations is calculated by Eq. 5 :

$$
\mathrm{SR}=\mathrm{F} / \mathrm{A}
$$

where, $\mathrm{SR}=$ Specific Resistance $\left(\mathrm{kNm}^{-2}\right)$ 

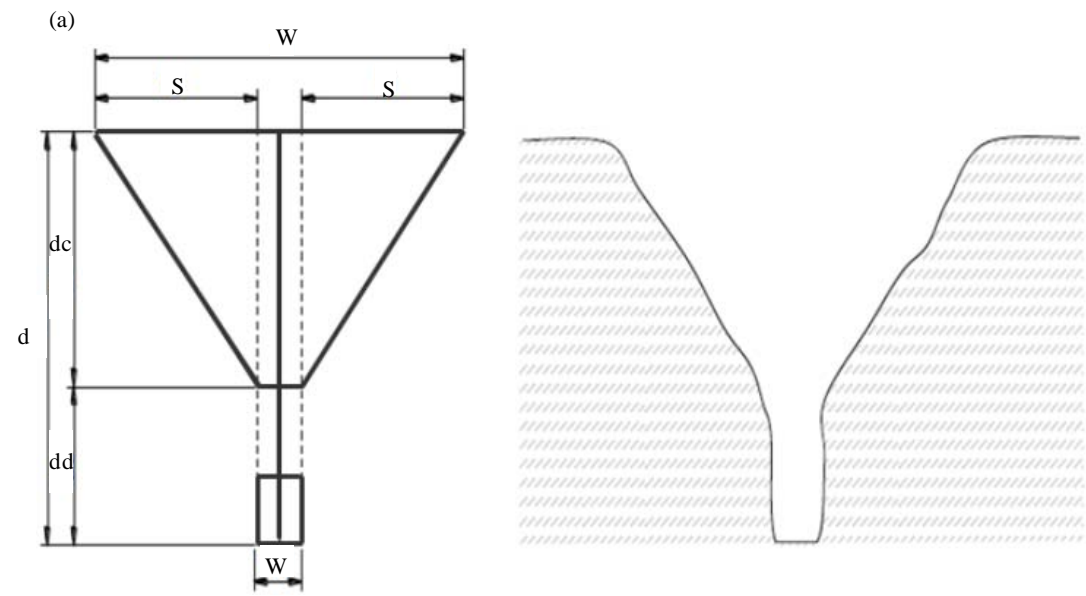

(b)
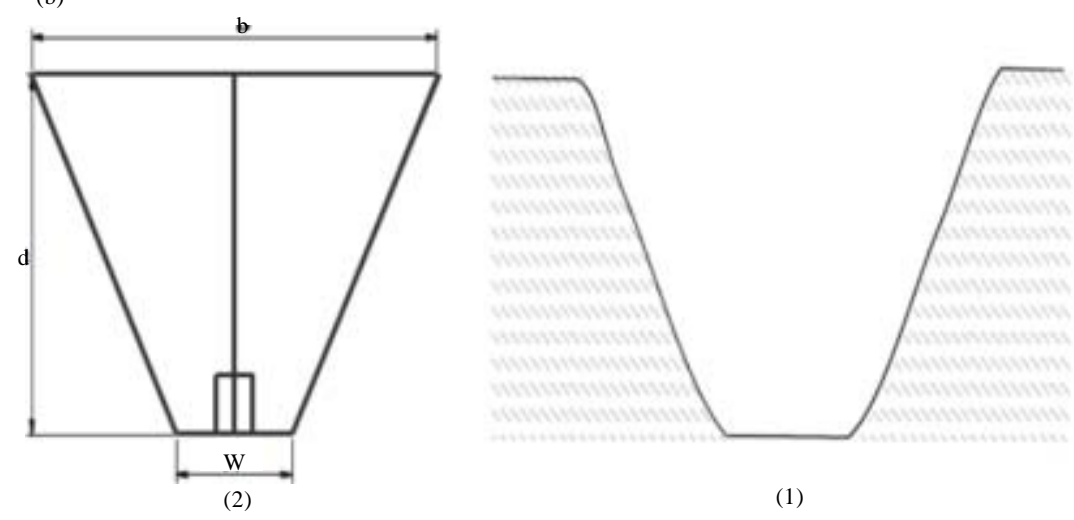

(1)

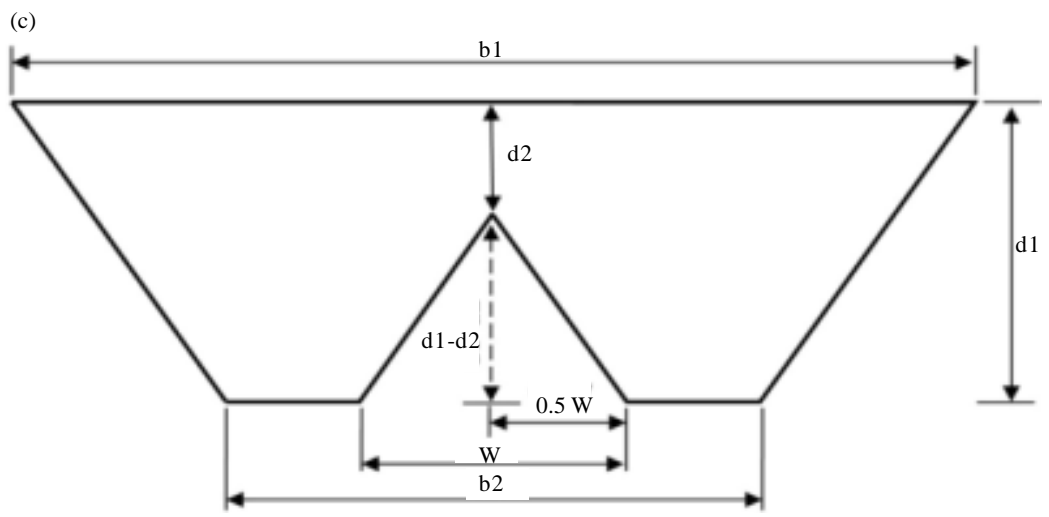

Fig. 4: The dimensions of the disturbed soil by SSP and SSV: a) Shape of the disturbed by single tine subsoiler without wings; b) The disturbed soil by the single tine subsoiler with wings and c) The disturbed soil by the double tines subsoilers (SSP and SSV)

Energy utilization efficiency: The energy utilization efficiency is calculated by Eq. 6 :

$$
\mathrm{EUE}=1 / \mathrm{SR}=\mathrm{A} / \mathrm{F}
$$

When Eq. 6 is multiplied and divided by $\mathrm{L}$ and multiplied by 1000 (to change $\mathrm{kJ}$ to $\mathrm{MJ}$ ) becomes as follows Eq. 7:

$$
\mathrm{EUE}=\mathrm{A}^{*} \mathrm{~L} / \mathrm{F}^{*} \mathrm{~L}=\mathrm{V} / \mathrm{E}^{*} 1000
$$


Where:

EUE $=$ Energy Utilization Efficiency $\left(\mathrm{m}^{3} \mathrm{MJ}^{-1}\right)$

$\mathrm{L} \quad=$ Length of the disturbed soil equal to $1 \mathrm{~m}$

\section{RESULTS AND DISCUSSION}

\section{Specific resistance}

The effect of the subsoiler combinations on the specific resistance: The Specific Resistance (SR) decreased for the three subsoiler combinations but the amount of reduction depends on their types, SSV reduced SR more than S and SSP while $\mathrm{S}$ surpassed SSP in reducing SR (Fig. 5). The values of SR are 92.91, 108.99 and $125 \mathrm{kNm}^{-2}$ for SSV, S and SSP, respectively. The supervision of SSV on S and SSP in giving lower SR is related to that it produced greater volume of disturbed soil with medium draft force requirement. However, for SSP it produced almost the same volume of disturbed soil of SSV but its draft force requirement was greater by big difference. For $\mathrm{S}$ the draft force was lower than that for SSV and SSP but produced smaller volume of disturbed soil.

The results showed that S supervised SSP in having lower SR despite of that SSP produced DA almost doubled of that produced by $\mathrm{S}$. This was because the draft force requirement for SSP was more than doubled of that for $\mathrm{S}$ and that was because the disturbed soil was chocked (blockade) between the two tines of SSP. The field experiments showed that the lateral distance between the two parallel tines was not wide enough to let the soil flow freely between them. However, increasing the lateral distance between the two parallel tines probably can solve the problem of soil flow but the aim of using double tines probably diminish because the two tines started operating separately or limitedly interacedt.

The effect of the wings on the specific resistance: When S, SSV and SSP were provided with wings their SR decreased considerably. The values of SR decreased from $92.90-66.67 \mathrm{kNm}^{-2}, 108.99-78.25 \mathrm{kNm}^{2}$ and $125.28-86.23 \mathrm{kNm}^{-2}$ for SSV, S and SSP, respectively (Fig. 6). The reduction in SR for the three subsoiler combinations was because the wings increased the volume of the disturbed soil by greater amount than its draft force requirement for the three subsoiler combinations. The lowest value of SR was recorded for $\mathrm{SSV}$, the second lowest value was recorded for $\mathrm{S}$ whereas the highest value was recorded for SSP. The bad performance of SSP compared with SSV and S was related to its high draft force requirement for the reasons mentioned above. The supervision of SSV was related to that the swerved arrangement of the double

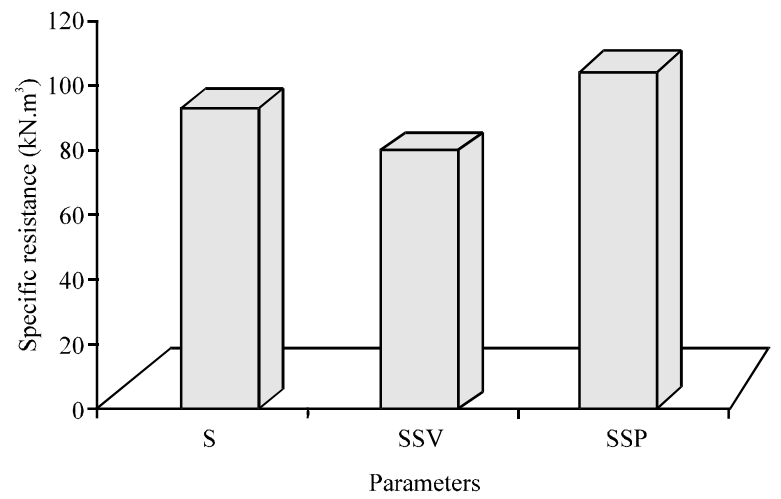

Fig. 5: The effect of the subsoiler combinations on specific resistance

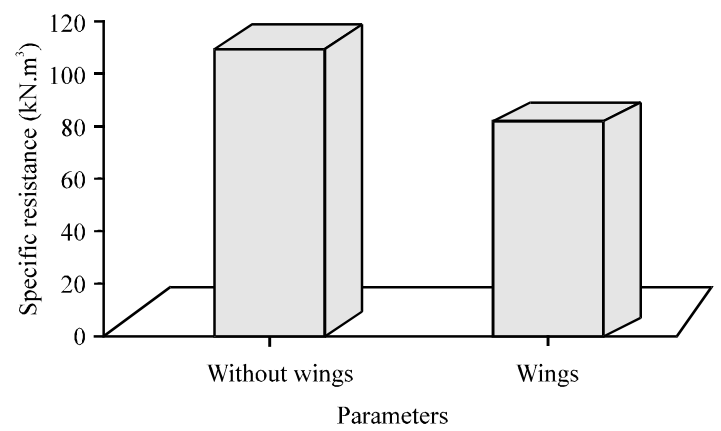

Fig. 6: The effect of the wings on specific resistance

tines did not suffer from the soil blockade and produce high disturbed volume of soil even when provided with wings.

The effect of the operating depth on the specific resistance: The operating depth significantly decreased SR for S, SSV and SSP and surpassed the subsoiler combinations and the wings in their effect on SR. The values of SR decreased from 149.45-90.42 $\mathrm{kNm}^{-2}$, $113.74-80.33 \mathrm{kNm}^{-2}$ and $167.03-98.74 \mathrm{kNm}^{-2}$ for S, SSV and SSP when the operating depth was increased from $30-60 \mathrm{~cm}$ (Fig. 7). This means the subsoiler combinations performance improved considerable as the operating depth increases despite of the increases in their draft force requirements. The reduction in SR with depth regardless of the higher soil cohesion, bulk density and confine pressure at depth (Table 1 and 2) was because the rate of increase in disturbed area is higher than the rate of increase in draft force requirements.

The interaction effect of the subsoiler combinations, wings and the operating depth on the specific resistance: SR for S, SSV and SSP decreased significantly when the effect of the three parameters interacted with each other. 
The values of SR for SSV, S and SSP decreased from $113.74-58.34 \mathrm{kNm}^{-2}(49 \%), 149.45-71.78 \mathrm{kNm}^{-2}(52 \%)$ and $167.03-72.04 \mathrm{kNm}^{-2}(57 \%)$ when they were provided with wings and their operating depth increased from $30-60 \mathrm{~cm}$ (Fig. 8). The results revealed that the differences between the values of SR for S and SSP are greater at the shallow operating depths but the values became closer as the operating depth increased. The reason was that at deeper operating depth the rate of increase in the disturbed volume of the soil by $\mathrm{S}$ decreased while its draft force requirement increased by grater rate. It can be deduced from the results of SR that SSV dominated S and SSP in its performance because it gave lower values of SR and that means SSV spent less power in manipulating bigger volume of soil.

\section{The energy utilization efficiency}

The effect of the subsoiler combinations on EUE: SSV gave the highest valve of EUE $\left(10.98 \mathrm{~m}^{3} \mathrm{MJ}^{-1}\right)$ while $\mathrm{S}$ became the second $\left(9.57 \mathrm{~m}^{3} \mathrm{MJ}^{-1}\right)$ and SSP third $\left(8.23 \mathrm{~m}^{3} \mathrm{MJ}^{-1}\right.$ ) (Fig. 9). This means SSV produced greater

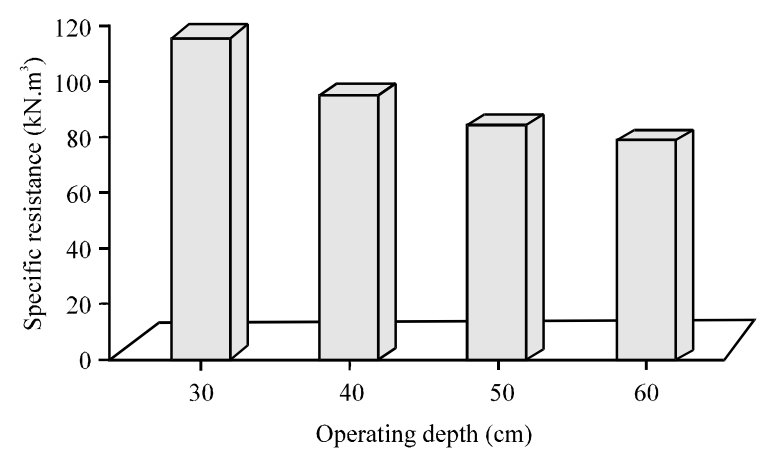

Fig. 7: The effect of the operating depth on specific resistance volume of soil and spent almost the same energy spent by $\mathrm{S}$ and SSP. The bad performance of SSP compared with S, produced lower value of EUE than S is rated to that SSP spent great amount of energy in moving the soil which piled up in front of its two tines instead of spending the energy in disturbing further volume of soil. However, the supervision of $\mathrm{S}$ was not because it disturbed greater volume of soil than SSP but it required less energy than SSP. Therefore, SSV is more efficient in energy spending than $\mathrm{S}$ and SSP.

The effect of the wings on EUE: When S, SSV and SSP were provided with wings, EUE improved clearly for the three combinations, especially for SSV. The values of EUE increased from $9.57-12.88 \mathrm{~m}^{3} \mathrm{MJ}^{-1}(34.5 \%), 10.98-15.15$ $\mathrm{m}^{3} \mathrm{MJ}^{-1}(38 \%)$ and $7.23-11.82 \mathrm{~m}^{3} \mathrm{MJ}^{-1}(43.6 \%)$ for $\mathrm{S}, \mathrm{SSV}$ and SSP, respectively (Fig. 10). This was because the wings disturbed greater volume of soil with less energy spending despite of that the wings operated at more compacted soil and higher moisture content (Table 1 and 2). The wings effect on EUE was through creating great number of cracks in the soil which started from their edges and developed in inclined path to meet the soil surface at points far from the tines path and that increased the volume of the disturbed soil considerably (Aday et al., 2001, 2004).

The effect of the operating depth on EUE: The operating depth considerably affected EUE. For example, when the operating depth of S, SSV and SSP was increased from 30-60 cm, EUE values increased from 6.73-11.06 $\mathrm{m}^{3} \mathrm{MJ}^{-1}(64 \%), 8.84-12.45 \mathrm{~m}^{3} \mathrm{MJ}^{-1}(40.8 \%)$ and $5.99-10.13$ $\mathrm{m}^{3} \mathrm{MJ}^{-1}(69 \%)$ (Fig. 11). The operating depth increased the volume of the disturbed soil considerably with less energy spent by S, SSV and SSP. Comparing the values of

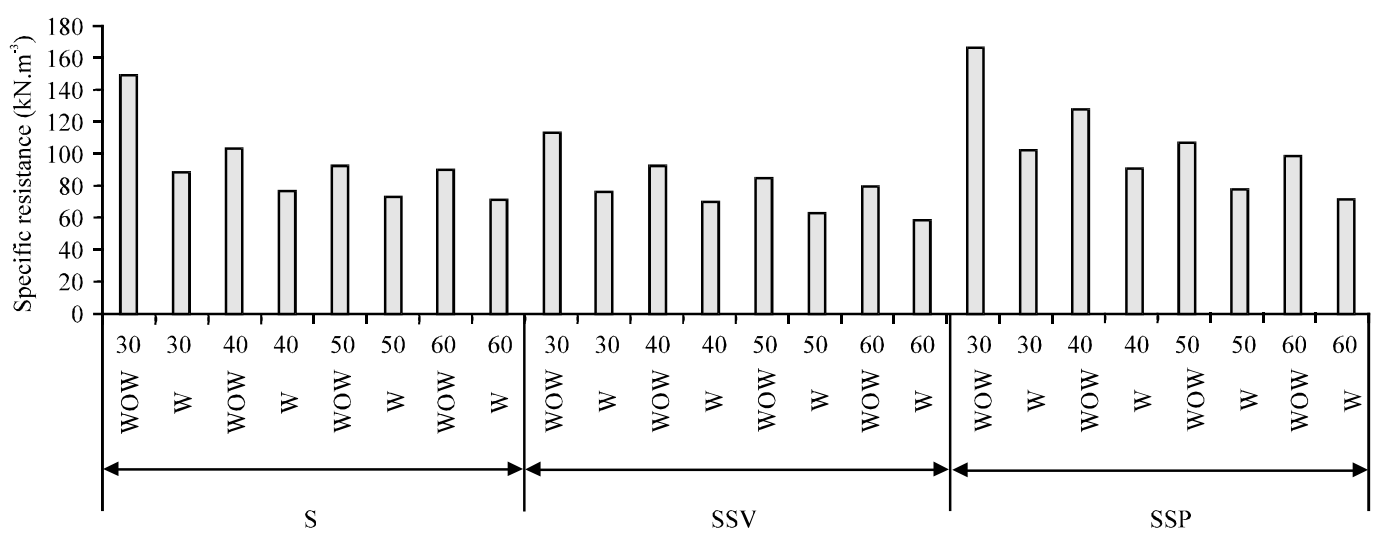

Fig. 8: The effect of the interaction of the subsoiler Combinations (S, SSV and SSP), the wings and the operating depth on the specific resistance (WOW $=$ Without wings, $\mathrm{W}=$ With Wings) 
EUE for S, SSV and SSP, it can be seen clearly that SSV surpassed S and SSP. However, the difference between the values of EUE for SSV and that for S and SSP decreased at deeper operating depths. For example, at

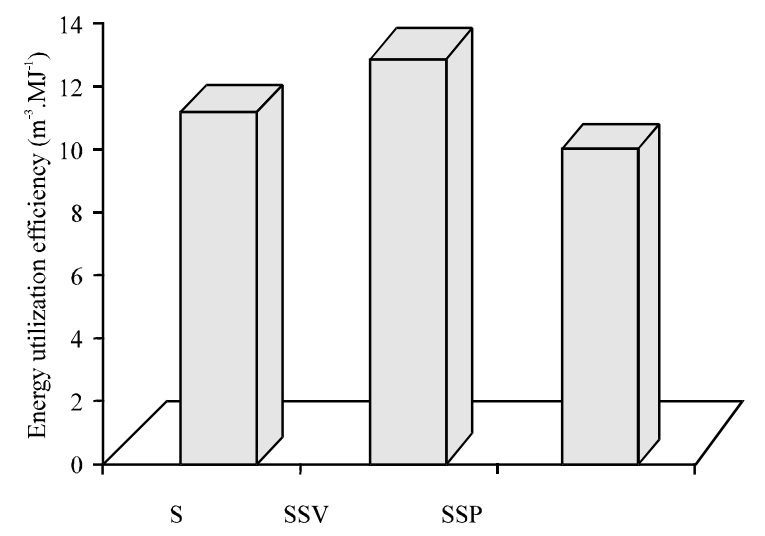

Fig. 9: The effect of the subsoiler combinations on energy utilization efficiency

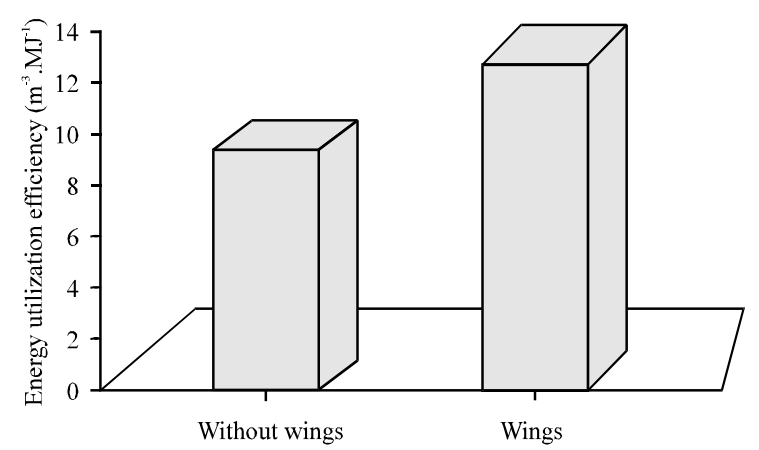

Fig. 10: The effect of the wings on energy utilization efficiency operating depth of $30 \mathrm{~cm}$ valves of EUE for SSV are higher by 31 and $47.6 \%$ while at operating depth of $60 \mathrm{~cm}$ it was only higher by 12.6 and $23 \%$ compared with that for $\mathrm{S}$ and SSP, respectively. For the other depths the differences between the values are medium.

The effect of the interaction between the subsoiler combinations, the wings and the operating depth on EUE: EUE for S, SSV and SSP almost doubled when the three subsoiler combinations were provided with wings and operate at greater operating depth. It increased from 6.73-13.93 $\mathrm{m}^{3} \mathrm{MJ}^{-1}(107 \%), 8.84-17.15 \mathrm{~m}^{3} \mathrm{MJ}^{-1}$ (94\%) and $5.99-13.88 \mathrm{~m}^{3} \mathrm{MJ}^{-1}(131 \%)$ for $\mathrm{S}, \mathrm{SSV}$ and SSP, respectively (Fig. 12). SSV gave higher values compared with values of $\mathrm{S}$ and SSP with big differences between the values. Using SSP did not improve EUE values compared with that for S in fact the contrary occurred, SSP produced lower value of EUE than S. The supervision of S on SSP was observed for all operating depths with wings and without them.

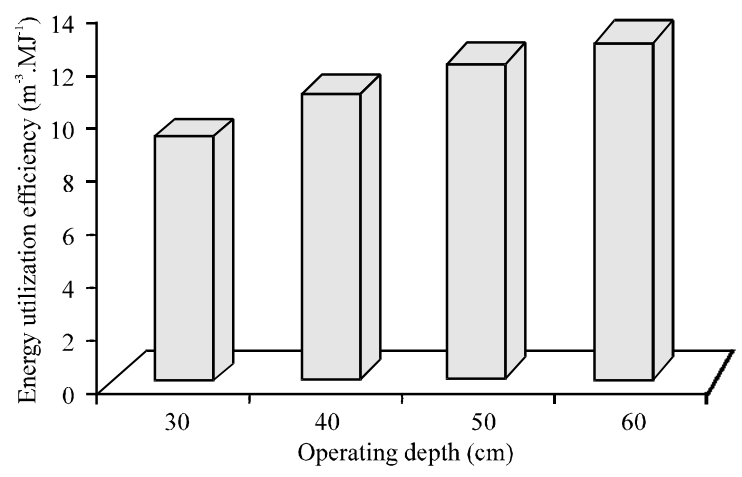

Fig. 11: The effect of the operating depth on energy utilization efficiency

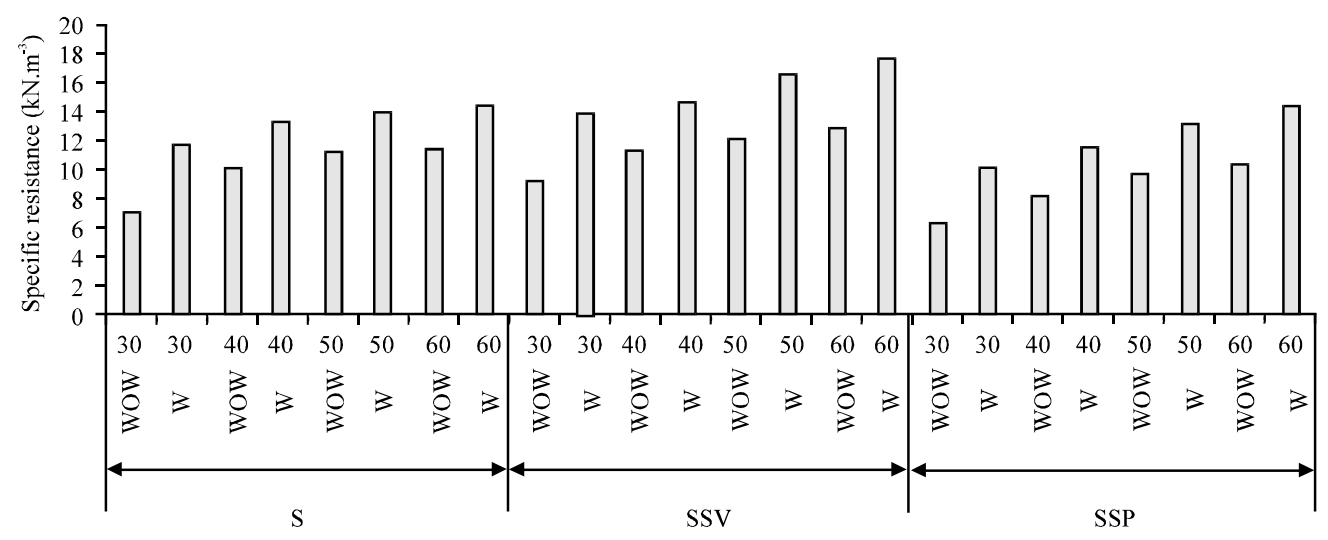

Fig. 12: The effect of the interaction of the subsoiler combinations, the wings and the operating depth on energy utilization efficiency 


\section{CONCLUSION}

The following conditions can be drawn from the results: the arrangement of the tines plays great role in determining the field performance of the subsoiler combinations. The best double tines arrangement is the partially swerved (SSV) with lateral interaction between the tines not $<25 \%$ and the longitudinal distance between the two tines preferred to be equals $(70 \mathrm{~cm})$. SSV had lower SR and higher EUE compared with SSP and S for all the operating depths tested without and with wings. S surpassed SSP in having lower SR and higher EUE for all operating depths tested without and with wings. The lowest value for $\mathrm{SR}\left(58.34 \mathrm{kNm}^{-2}\right)$ and the highest value for EUE $\left(17.15 \mathrm{~m}^{3} \mathrm{MJ}^{-1}\right)$ were recorded for SSV while the second lowest value for SR $\left(71.78 \mathrm{kNm}^{-2}\right)$ and the second highest value for EUE $\left(13.93 \mathrm{~m}^{3} \mathrm{MJ}^{-1}\right)$ were recorded for $\mathrm{S}$ at the deepest operating depth $(60 \mathrm{~cm})$ without and with wings. The performance of parallel double tines subsoiler (SSP) was less than the other two subsoiler combination. The great problem which SSP suffered from was the low soil flow between its two tines, soil blockade.

\footnotetext{
ABBREVIATIONS

$\mathrm{S}=$ Conventional subsoiler (single tine)

SSP $=$ Double tines parallel arranged subsoiler

SSV = Partially swerved double tines subsoiler

$\mathrm{SR}=$ Specific Resistance

$\mathrm{EUE}=$ Energy Utilization Efficiency

DA $=$ The cross-section area of the disturbed soil
}

\section{REFERENCES}

Aday, S.H., 2005. The field performance of a laterally inclined mole plough. Proceedings of the 15th International Conference on International Society for Terrain-Vehicle System (ISTVS), September 25-29, 2005, Hayama, Japan, pp: 3-39.
Aday, S.H., 2012. Predicting the draft force and the energy utilization efficiency of longitudinally arranged double tines Subsoiler. Proceedings of the 17th International Conference on International Society for Terrain-Vehicle System (ISTVS), September 18-22, 2012, Blacksburg, Virginia, USA., pp: 80-100.

Aday, S.H., H.R. Majid and A. Al-Haliphy, 2004. Energy utilization efficiency of a modified subsoiler in heavy soils (Part3). J. Babylon Univ., Vol. 6,

Aday, S.H., K.A. Hamid and R.F. Salman, 2001. Energy requirement and energy utilization efficiency of two plow types for pulverizing the heavy soils. Iraqi J. Agric., 6: 137-146.

Godwin, R.J. and G. Spoor, 1977. Soil failure with narrow tines. J. Agric. Eng. Res., 22: 213-228.

Godwin, R.J., G. Spoor and M.S. Soomro, 1984. The effect of time arrangement on soil forces and disturbance. J. Agric. Eng. Res., 30: 47-56.

McKeys, E. and J. Maswaure, 1997. Effect of design parameters of flat tillage tools on loosening of a clay soil. Soil Tillage Res., 43: 195-204.

McKyes, E. and F.L. Desir, 1984. Prediction and field measurements of tillage tool draft forces and efficiency in cohesive soils. Soil Tillage Res., 4: 459470.

McKyes, E. and O.S. Ali, 1977. The cutting of soil by narrow blades. J. Terramech., 14: 43-58.

O'callaghan, J.R. and P.J. McCullen, 1965. Cleavage of soil by inclined and wedge-shaped tines. J. Agric. Eng. Res., 10: 248-254.

Owen, G.T., 1988. Soil disturbance associated with deep subsoiling in compact soils. Can. Agric. Eng., 30: 33-37.

Ramadan, M.N., 2011. Evaluation of the mechanical performance of the double tines longitudinally arranged subsoiler and its effect on some growth characteristic of barley crop. MSc Thesis, University of Basrah, Basra, Iraq. 